\title{
Professional service firms and their strategic renewal: \\ Evidence from Germany's legal advisory industry
}

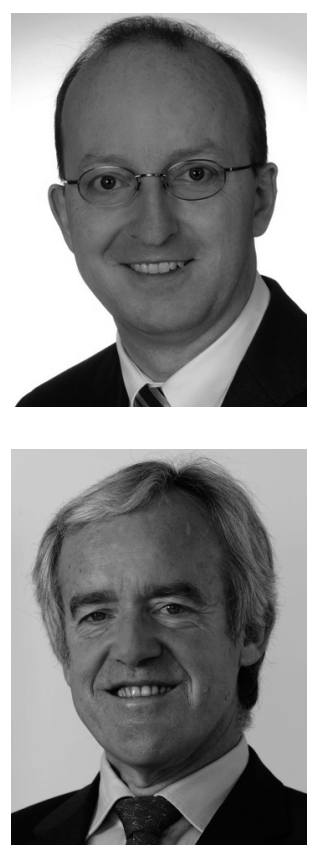

Kai-Christian Muchow \&̋ Günter Müller-Stewens

Professional Service Firms, legal advisory industry, law firms strategic renewal, cognitive structures, evolutionary theory

Anwaltskanzleien, strategischer Wandel, kognitive Strukturen, Evolutionstheorie

Drawing on evidence from Germany's legal advisory industry, this study analyses - from an evolutionary perspective - how professionals' existing cognitive structures develop in processes of strategic renewal under turbulent environmental conditions, as well as how such development is guided by interplays with corresponding sets of mutually interrelated organisational activities. Against the empirical backdrop of the transformation of Germany's legal advisory industry, which took place between 1998 and 2002, two concepts for describing generic configurations of organisational activities in professional service firms are developed.

\section{Introduction}

Owing to its growing contribution to developed countries' total value creation and its key role in facilitating the dissemination of knowledge and technology, the professional services sector has received increasing attention in management literature since the early 1990s (e.g. Greenwood et al. 1990, 1994; Scott 1998; Covaleski et al. 1998; Müller-Stewens et al. 1999; Empson 2000, 2001; Leel Pennings 2002; Kaiser/Ringlstetter 2010, McKenna/Maister 2002; Sherer/Lee 2002; Dunn/ Baker 2003; Maister 2003; Løwendahl 2005; Greenwood et al. 2005; Grewe 2008). This industry's dynamic evolution is a vivid example of the new challenges to the theory of strategic management in the post-industrial age (Løwendahl and Revang 1998). Given the relevance of professional services as a management research study field, this paper investigates strategic renewal processes in the legal advisory industry, a segment that has in recent years been among the most dynamic within the professional services sector. Owing to the changes in the external business context - such as the globalisation of client markets, the emergence of new multinational competitors, and the rapid shifts in information technologies - law firms in many countries find themselves under increasing pressure to renew strategically. Many of them still follow an opportunistic business model, avoiding a clear strategic positioning. Some senior professionals see themselves as unique experts in a group of artists, with the firm merely providing the necessary infrastructure for their invaluable professional contributions. 
Drawing on empirical evidence from Germany's legal advisory industry, our study analysed how professionals' existing cognitive structures evolve in processes of strategic renewal under conditions of environmental turbulence (Burgelman 1994, 1996; BadenFuller/Volberda 1997; Floyd/Lane 2000; Chakravarthy/White 2002), and how these structures are guided by their interplays with sets of mutually interrelated organizational activities (Nelson/Winter 1982; Porter 1996; Siggelkow 2002; Evans/White 2005; Gmür et al. 2009). Specifically, we address the following research questions:

- How are existing cognitive structures transformed by strategic renewal processes in the context of environmental turbulence?

- How do changing cognitive structures impact the chances of organisational survival in the context of environmental turbulence?

While the first research question seeks to identify patterns of cognitive change in processes of strategic renewal, the second examines the intervening conditions that ensure organisational survival, especially when renewal initiatives turn out to be unsuccessful.

\section{Changing bundles of interrelated interpretations}

To identify specific developmental patterns that help describe the evolution of cognitive structures in the context of organisational change, Isabella (1990) empirically analysed how interpretations of specific environmental events are modified within an organisation in the course of such change processes. Based on the results of a single-case study in the financial services industry, she developed a four-stage developmental model of how interpretations of internal events are gradually elaborated from diffuse to more specific concepts. According to the model, each of the four developmental stages - anticipation, confirmation, culmination and aftermath - is characterised by a specific set of dominant cognitive structures and activities. In the anticipation stage, interpretations are based on rumours or conjectures, while in the confirmation stage, individuals derive their interpretations from conventional explanations and historical experience. In the culmination stage, these conventional explanations are abandoned, and interpretations become more differentiated. Finally, the aftermath stage is characterised by a focus on evaluating the observed event and its consequences (e.g. winners and losers). The results of Isabella's study suggest that the transitional periods between the developmental stages are influenced by the type and amount of the information available at the individual level as well as by the credibility of the specific information source, while the sequence of the transitional periods largely corresponds to the unfreeze-move-refreeze model suggested by Lewin (1947).

In contrast to Isabella (1990), whose study specifically dealt with the dynamic interpretations of internal environmental events, Barr (1998) analysed the development of interpretations concerning unfamiliar or entirely novel events from outside the organisation, thus shifting the analytical focus to the external organisational environment. Based on the analysis of historical data from the pharmaceutical industry, Barr developed a model that predicts the occurrence of specific change patterns of managerial cognitive structures, depending on the degree of familiarity of managers with observed environmental events. From the results of her study, Barr concluded that the occurrence of the two identified cognitive change patterns depended on whether the perceived environmental events were unknown/unfamiliar or known/familiar to the managers. In the case of unfamiliar or hitherto unknown events, interpretations developed over time according to the four-stage 
model suggested by Isabella, i.e. from diffuse and vaguely defined ideas, to the more elaborated and precise concepts that formed the cognitive basis for the specific organisation's strategic behaviour. In contrast, in the case of familiar or already known events, the already existing interpretations were re-interpreted, mutually interrelated by new causal connections, and occasionally replaced by new concepts, although their degree of specificity did not change over time, contrasting with Isabella's findings. However, it must be noted that Barr conducted her study in an industry that underwent change between 1959 and 1970 and that is not representative of an industry context characterised by environmental turbulence, which our study sought to address.

\section{Shifting from relationship lawyering to transaction lawyering}

Germany's legal advisory industry, which underwent a fundamental transformation between 1998 and 2002 owing to intense cross-border merger activity, provided us with the opportunity to address our research questions in a very turbulent competitive environment. Referring to two concepts that we found as in vivo codes in our empirical study, one of the most important characteristics of this industry transformation was the shift from relationship lawyering to transaction lawyering. The relationship lawyering approach relies on highly flexible, decentralised structures as well as on organisational routines with low degrees of formalisation and financial control, which enable professionals to provide highly customised advisory services to their clients. Key success factors are seniority and experience of autonomous professionals with stable, informal relationships with their clients, which means that clients tend to value local content over a firm's international reach. As a result, partnerships that follow this approach usually focus on individual national or even regional markets and seek to cover cross-border mandates via international alliances rather than cross-border mergers. Owing to the high degree of partner autonomy and the strong focus on client relationships with a limited number of key individuals, these partners largely represent the firm itself and its source of competitive advantage. Hence, the leverage ratio between employed lawyers with non-partner status and partners is low (usually < 2), with the effect that the intra-firm division of labour is equally low, while for newly hired lawyers, professional content is fairly rich and therefore potentially attractive, typically covering the whole area of legal practice (e.g. banking and capital markets law).

In contrast, the transaction lawyering approach is characterised by organisational routines with a strong focus on the swift and successful completion of large projects or transactions. Owing to such projects' size and complexity, a high degree of co-ordination of intra-firm operations is required, which usually materialises in partner hierarchies with high leverage (usually at least four lawyers per partner), increased organisational distance between junior and partner levels, and a stronger division of labour. Although the recruitment of highly qualified professionals remains an important issue, such firms' dependence on individual partners is significantly lower. As a result, the firm's most critical strategic resources are represented by organisational structures and procedures rather than by key professionals, which may contribute to the attractiveness of transaction lawyering firms in the eyes of legal professionals. From the perspective of freshly graduated lawyers, another benefit of working in such a firm may lie in the opportunity to develop a particular depth of expert knowledge by working on a large number of mandates in a specific field, albeit 
not covering a whole practice area. In addition, company size is considered a critical success factor for future competition.

Based on the distinction between relationship lawyering and transaction lawyering, we focused on the renewal processes of law firms shifting from the former to the latter approach. In the industry context of professional service firms, both approaches represent viable alternative responses to environmental change and are associated with specific sets of organisational goals, activities and corresponding cognitive structures (for a description of similar though not fully congruent concepts, see Greenwood et al. 1990; Cooper et al. 1996; Løwendabl 2005; Brock 2006). This is also true from a financial perspective, since the results from our analysis of available financial data on the top-tier German law firms suggest that partnerships that were clearly positioned as following either of the two approaches were able to reap a profit per partner of up to $€ 0.8 \mathrm{~m}$, whereas some of the more diffusely positioned firms that were "stuck in the middle" only earned about half this amount per partner. Hence, law firms' (and professional partnerships in general) choosing between the two approaches seems to be primarily driven by professional content rather than by financial considerations (Greenwood/Empson 2003). Figure 1 summarises the characteristics of relationship lawyering and transaction lawyering.

Sticking to relationship lawyering

- Maintaining intra-firm diversity (focus on individual autonomy)

- Consensus-building processes and structures (partnership meetings on strategic issues; $1-2$ core offices)

- Flexible, decentralised organisational structures

- Flat hierarchies

- Low level of internal co-ordination, formalisation and managerial control

- Personal client relationships and individual reputation of partners as key assets (controlled by people)

- Focus on specific legal areas

- Professional excellence is key
Migrating to transaction lawyering

- Fostering vertical differentiation

- Centralising organisational structures

- Increasing the level of internal coordination, formalisation and managerial control

- Knowledge embedded in structures and processes as key assets (controlled by firm)

- Offering advisory services in all legal areas (full service approach)

- Professional excellence is achieved through internal coherence and standardisation

- Extensive training measures offered to professional staff

- Growth \& profitability is key

Figure 1: The choice between relationship lawyering and transaction lawyering

Concerning the debate in strategy theory between the content-oriented and process-oriented approaches, the two generic strategy types (relationship lawyering and transaction lawyering) can be considered as two competing configurations of ongoing organisational activities (Porter 1985, 1996; Siggelkow 2002; also, see Maister 2003). These activities determine the ways in which organisations achieve, hold and occasionally withdraw from 
defined strategic positions (Chakravarthy/Doz 1992). Thus, from a process perspective, a law firm's choice of a particular strategic position is equivalent to the decision in a highly specific configuration of organisational activities that seek to achieve a defined competitive advantage (Porter 1996; Siggelkow 2002; Greenwood et al. 2005). At the cognitive level, this configuration of activities is reflected by a bundle of corresponding, mutually interrelated interpretations that may be temporarily incongruent with the existing activity set in the course of organisational transformation, but should be brought back into alignment in periods of organisational consolidation. The distinction between the activity and cognitive levels within the organisational context, which is made here for reasons of analytical clarity, largely corresponds to the distinction between behavioural and contextual or conceptual aspects in strategy process research (Burgelman 1983a).

Based on an analysis of how strategy process patterns are related to the interplay between strategy process and external context (Porter 1980) as well as internal context (Barney 1991; Eisenhardt/Martin 2000), Chakravarthy/White (2002) developed a framework for describing strategy process patterns. According to their framework, the change in a firm's strategic position is associated with a process labelled strategic migration. At the cognitive level, the process of strategic migration is associated with a shift from one existing bundle of mutually interrelated interpretations to another. Furthermore, the restructuring of the top-level segment of Germany's legal market highlights how existing sets of guiding strategic ideas in specific industries (e.g. relationship lawyering vs. transaction lawyering in the legal advisory industry) can become the cognitive basis for the emergence and evolution of strategic groups (Huff 1982; Porac et al. 1989; Reger/Huff 1993; Abrahamson/Fombrun 1994; Osborne et al. 2001; Volberda et al. 2001). From this perspective, the process of migrating existing cognitive structures in which an industry recipe (Spender 1989; Lounsbury 2002) that exists in an organisation is replaced by a new recipe frequently coincides with the shift from one strategic group to another. Occasionally, this process can also lead to the emergence of an entirely new strategic group.

The concept of strategic groups, which is rooted in classical industry structure analysis (Porter 1980), draws on a description of an industry's competitive environment along adequate strategic dimensions (e.g. level of specialisation, brand identification, quality, price, cost position, etc.). Organisations with similarities along one or several strategic dimensions can be aggregated in strategic groups within that industry. The identification of strategic groups within a particular industry by using selected strategic dimensions provides an important frame of reference for analysing that industry's competitive environment as well as the potential performance differences of organisations within specific strategic groups. In strategic practice, the comparison between a company's relative cost position and its differentiation level (Porter 1996; Chakravarthy/White 2002) has been the single most relevant approach for describing strategic groups and the shifts of single competitors between these groups. The simplified form of description based on the selection of only two characterising strategic dimensions also permits the graphical representations of the structural positions of the different strategic groups and the competitors associated with these groups within that industry (Figures 2 to 4). In the case of Germany's legal advisory industry, the two criteria that appeared to be most appropriate for describing the existing strategic groups as well as for the two main thrusts of strategic renewal in the industry between 1998 and 2002 were the company's level of internationalisation (i.e. its geographical reach and its ability to offer a 'one-stop' offering to their clients, as measured by the 
ratio of the number of international offices and the total number of offices maintained by a partnership) (Melin 1992; Løwendahl 2005) and its leverage (i.e. the numerical ratio between partners and non-partners).

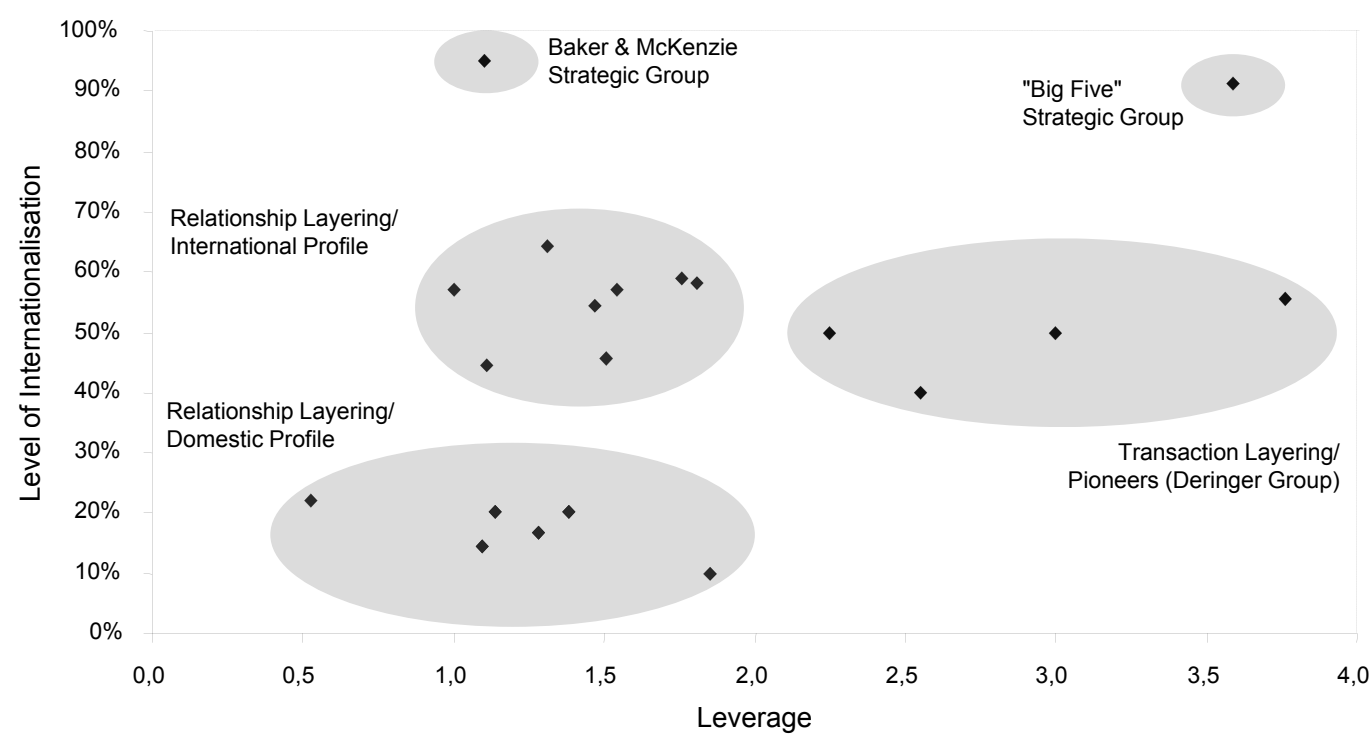

Figure 2: Map of strategic groups as at 1998 to 1989

Based on these two dimensions (internationalisation level and leverage), which help to describe two generic, conflicting strategy types, the top 20 firms in Germany's legal market can be described as falling into four strategic groups. The group that was the largest at the start of the merger wave in 1998 included the firms in the traditional German law firm model, with low leverage and a moderate or low degree of internationalisation. The strategy of firms affiliated with this group - which can be conceived either as one or two strategic subgroups, depending on whether differences in the degree of internationalization are taken into account - is guided by the concept of relationship lawyering. Partnerships like Hengeler Mueller and Gleiss Lutz are good examples of this strategic group. In contrast, the second group's approach is characterised by high leverage and moderate internationalisation, which is reflected by a high percentage of lawyers admitted to courts in other countries and more offices in other countries. The prototype of this second approach, which corresponds with transaction lawyering, is Clifford Chance, a London-based law firm founded in 1988 that has subsequently expanded aggressively abroad. The primary growth vehicle following this second approach was mergers with other law firms. With its high leverage and strongly international profile, this approach has explicitly or implicitly become a role model for many German law firms. In Germany, Schürmann \& Partner, Deringer Tessin Herrmann \& Sedemund, Haarmann, Hemmelrath \& Partner, and Nörr, Stiefenhofer \& Lutz were early examples of this approach, regardless of their modest size and distinctive characteristics.

Compared to the first two groups, Döser Amereller Noack, which was part of worldwide partnership Baker \& McKenzie, held a unique position in Germany's legal market owing to its low leverage and high internationalisation, thus constituting a group on its 
own. The fourth strategic group among the top 20 German law firms comprises the legal advisory firms affiliated with the 'big four' accounting firms, which combine high leverage with a high internationalisation, thus following the transaction lawyering model. In contrast to other legal markets in continental Europe (especially France), this strategic group only played a minor role among top-tier German law firms until 1998. Before the takeoff of the merger wave among German law firms, Andersen Luther (until 2000, Andersen Freihalter) was the only firm from this group that had managed to establish itself among the 20 biggest partnerships. The legal advisory units of the 'big four' accounting firms have subsequently undertaken great efforts to enter the top-level market segment. However, the more established law firms have been largely successful in defending their positions against this strategic group.

Although relationship lawyering and transaction lawyering basically offer the same types of advisory services, the two approaches differ concerning the specific ways in which these services are provided. On the client side, this distinction corresponds with differentiated behaviour regarding choice of law firm. As a result, the competitive relationships among the top 20 partnerships in Germany's legal market was characterised by low levels of intra-industry rivalry until 1998. The size of the existing strategic groups varied widely, because most top-level law firms still adhered to the traditional approach, and size was not critical. The remaining strategic groups only encompassed one to four partnerships. In total, these groups could not exert much competitive pressure on the large group of traditional law firms. Intra-industry rivalry was also moderated by a general consensus among lawyers on the strategic principles of the legal advisory business and a low level of competitive awareness among the top-level firms, irrespective of their specific ways of providing legal advisory services.

By 2000, Germany's legal market presented a fairly diffuse picture owing to the numerous strategic moves by the top-level law firms since the start of the consolidation wave in 1998. In general, both the share of highly leveraged partnerships and the share of strongly internationalised firms had increased, primarily as a result of the forays initiated by the 'big four'-affiliated partnerships to enter the industry's premium segment. Among the highly leveraged firms, the strategic groups had been completely dissolved. In contrast, partnerships with low leverage and a high affinity for relationship lawyering revealed an increasing level of differentiation among internationally oriented firms and partnerships with domestic foci. The size of the group of internationally oriented firms with a relationship lawyering approach also declined significantly.

In the course of the further consolidation of Germany's legal market, which also featured several cross-border mergers, the strategic groups regained coherence and shape. By early 2002, there was no law firm left in the top-level segment that combined low internationalisation $(<70 \%)$ with a leverage of two or more lawyers. All partnerships that had hitherto populated this segment had either increased their internationalisation level, decreased their leverage, or both. As a result, a strong strategic group emerged that was guided by transaction lawyering, thus indicating the rise of a new dominant strategic paradigm in Germany's legal market. At the same time, some law firms with low leverage and high affinity for relationship lawyering either abandoned the group with domestic focus or disappeared altogether. In this context, the most noteworthy event was the dramatic breakup of Gaedertz, a highly esteemed partnership. 
The shape of Germany's legal market during the final stage of the industry consolidation in 2002 stands in sharp contrast to the competitive situation as at 1998. Although the strategic groups' positions had not changed significantly, only few competitors were left within the relationship lawyering group of top-level partnerships that still adhered to the traditional approach based on long-term client relationships. The dominant strategic group now leaned towards a transaction lawyering approach. Its members included the 'big four' law firms Luther Menold (Ernst \& Young), PwC Veltins and KPMG Beiten Burkhardt as well as the partnerships Freshfields Bruckhaus Deringer, Clifford Chance Pünder, Linklaters Oppenhoff \& Rädler, Lovells, White \& Case Feddersen, and Shearman \& Sterling, all of which had emerged from cross-border mergers. As a result of the merger wave between 1998 and 2002, which was concluded with the merger of Andersen Luther and Menold \& Aulinger, three of the 'big four' law firms found themselves in strong positions in the top-level segment of Germany's legal market. In contrast, only five competitors with international foci and four competitors with more domestic foci remained in the relationship lawyering group of traditional partnerships. A unique position within the top 20 segment was held by Döser Amereller Noack / Baker \& McKenzie, which combined low leverage with high internationalisation, despite efforts within the partnership to tighten up leadership structures that leaned towards the transaction lawyering model. In summary, besides the case of Baker \& McKenzie, Germany's legal market had largely adopted a dyadic structure by the end of the industry consolidation in 2002, with a relationship lawyering group combining low leverage and low internationalisation, and a transaction lawyering group combining high leverage and high internationalisation.

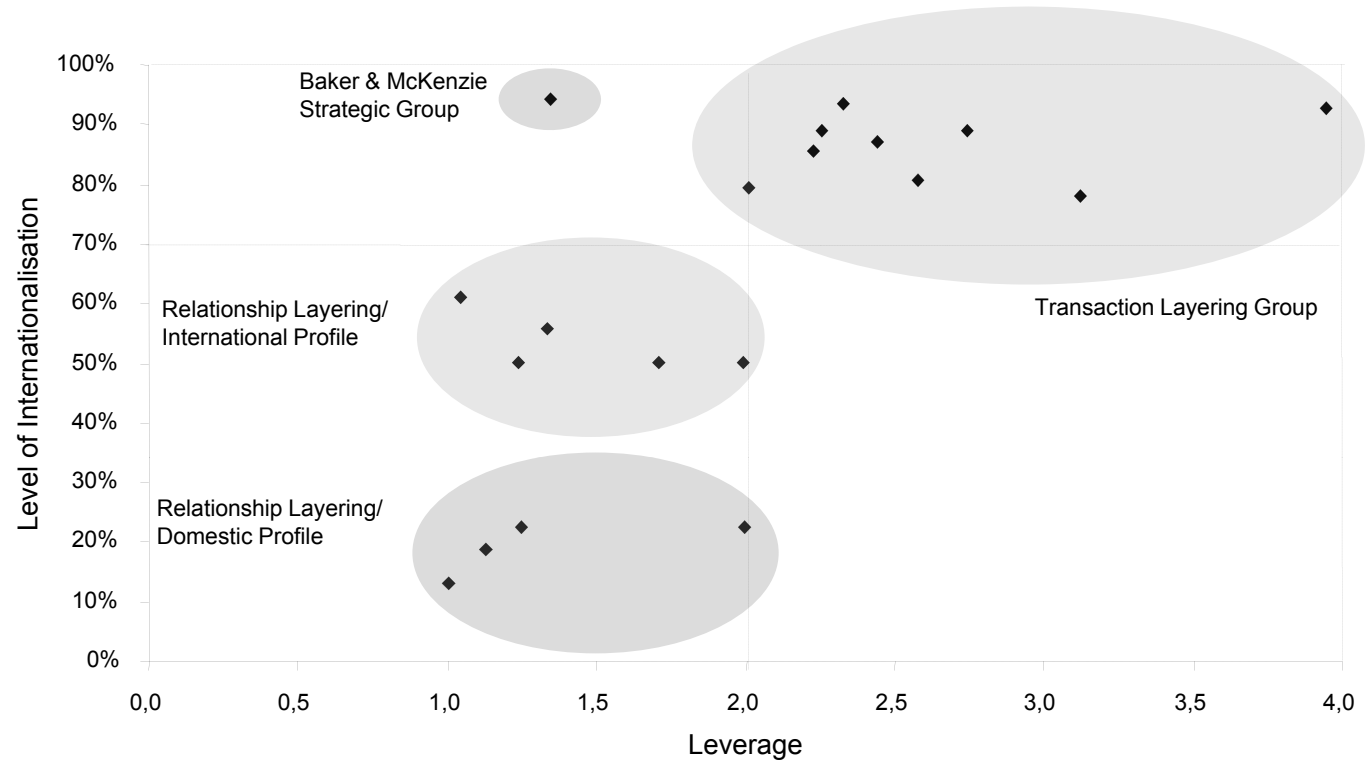

Figure 3: Map of strategic groups as at 2002 to 2003

For a large majority of the top 20 law firms in Germany's legal market, one very significant outcome of the industry structure changes between 1998 and 2002 was increased industry rivalry. Within the dominant group of law firms, which leaned towards transaction 
lawyering, a large number of partnerships of varying origins but similar approaches in terms of the delivery of legal advisory services now competed for the same client segment. Among the 'big four' law firms as well as the multinational partnerships, the shift from relationship lawyering to transaction lawyering became an industry recipe (Spender 1989; Lounsbury 2002) and hence the dominant frame of reference regarding the success factors for competing in the top-level segment. From an industry structure perspective, it also implied the migration from one strategic group to another (Porter 1980; Chakravarthy/White 2002).

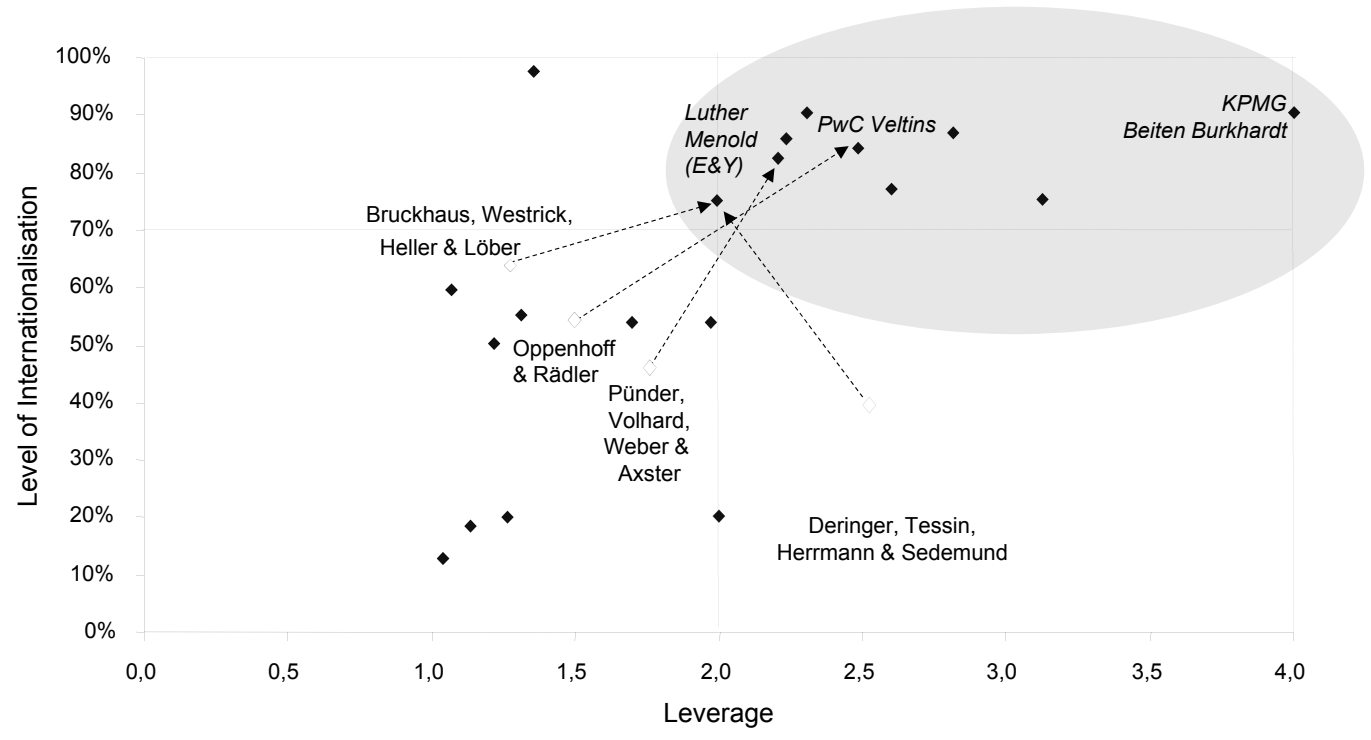

Figure 4: Transition to the transaction lawyering group

A diverging strategic approach was reflected in the competitive behaviour of partnerships that had not followed the industry trend but had stuck to the traditional model. This specific form of inertia frequently coincided with professionals' awareness of competition between law firms in the transaction lawyering approach, a notion that challenged the hitherto existing, consensus-driven self-perception of German lawyers. The traditionally oriented partnerships distinguished themselves from transaction-oriented partnerships by focusing on legal work that relied primarily on the opportunity to establish a stable, personal client relationship, rather than on the ability to make a large number of lawyers available at short notice for advising on a specific transaction. On the recruiting side, it is noteworthy that this approach became increasingly successful over time by attracting many young legal professionals who were specifically oriented towards the traditional concept of a lawyer.

Against the backdrop of the German legal market's consolidation, the increasingly exceptional role of the traditionally oriented law firms implied a decreasing rivalry in their own strategic group. Thus, the paradoxical outcome of the emergence and rise of a new industry recipe was that those partnerships that had abstained from following the industry recipe ended up with the most favourable competitive positions in the course of the indus- 
try consolidation. Among these were the highly esteemed partnerships Hengeler Mueller, Gleiss and Taylor Wessing. Although the latter had formed a bi-national law firm with a British partner, it continued to adhere to the relationship lawyering approach. As at 2002, two other interesting cases in this strategic group were Haarmann Hemmelrath and Nörr as well as Stefenhofer \& Lutz. Both had leaned towards transaction lawyering at an early stage of the industry consolidation, but had not succeeded in increasing their leverage and their internationalisation level to the same extent as their peers. It can be hypothesised that this might be due to their specific interpretations of transaction lawyering, which were strongly focused on organic growth rather than cross-border mergers. As a result, both law firms ended up with the structural characteristics of a traditionally oriented partnership, but followed a transaction lawyering approach in the way they provided their legal advisory services, thus placing themselves in a contradictory competitive position. It should be noted that after our study was concluded in 2002, Haarmann Hemmelrath suffered a massive loss of partners in the summer of 2005, including founding partner Wilhelm Haarmann, who cited disagreement over strategic issues as a reason for his departure.

The process of structural change within the top-level segment of the German legal advisory industry highlights how strategic principles can guide the emergence and change of strategic groups within a specific industry (Huff 1982; Porac et al. 1989; Spender 1989; Reger/Huff 1993; Abrahamson/Fombrun 1994; Osborne et al. 2001; Volberda et al. 2001). The migration of an individual competitor from one strategic group to another can be described as a process of replacing an existing industry recipe or business model in an organisation with a new one, i.e. as a change of cognitive structures. We will now address the question how a change of cognitive structures unfolds in the context of knowledgeintensive firms.

\section{Conduct of study and methodology}

The selection of empirical cases focused on law firms that had been subject to processes of strategic renewal, either through the formation of mergers or alliances with other major professional service firms, or through internal growth measures. In this respect, the German market appeared especially suitable, since it was among the most dynamically evolving legal markets in Europe at the time of our study. The merger wave among law firms, which had been triggered in the late 1980s, had resulted in what some of our respondents described as a complete transformation of the industry. In Germany, the number of toptier law firms had dramatically shrunk from 100 to about 20 within a decade. Having identified the top 20 firms (in terms of size of professional staff), the empirical fieldwork was carried out in five major German law firms. Two of which were or already had been involved in the formation of a cross-border merger, and in a third case, change was achieved through internal growth measures, rather than through a merger. At the cognitive level, these three partnerships all underwent a process of large-scale organisational transformation that implied a complete rearrangement of the existing bundle of interpretations. Among the remaining two cases in which no organisational change occurred, one partnership survived, whereas the other did not. In the period of our study, between 1998 and 2002, no empirical case of a partnership combining change and no survival occurred among Germany's top 20 law firms. In all the considered cases, field access was estab- 
lished through existing contacts with lawyers mostly working as legal advisors on financial issues for corporate clients. The case selection is summarised in Figure 5.

\begin{tabular}{|c|c|c|}
\hline \multirow{2}{*}{ Strategic behaviour } & \multicolumn{2}{|c|}{ Organisational success } \\
\cline { 2 - 3 } & Survival & No survival \\
\hline Change & $\begin{array}{c}\text { Alpha (merged) } \\
\text { Delta (merged) } \\
\text { Epsilon (did not merge) }\end{array}$ & - \\
\hline No change & Beta (did not merge) & Gamma (did not mnerge) \\
\hline
\end{tabular}

Figure 5: The selection of empirical cases

Among the five cases selected for our empirical study, the first partnership - Alpha - had been formed in the course of the 1990s as a result of several mergers between smaller law firms, some dating back to the first half of the 20th century. At the time of the study, the partnership was engaged in a cross-border merger with a major law firm, which put the combined entity among the top 10 partnerships worldwide in terms of the total number of lawyers employed. The governance structure was characterised by a somewhat more differentiated though still egalitarian system of managing and non-managing partners - all with equity stakes and equal voting rights - which was to be largely retained in the future governance structure. The new organisational structure was characterised by a matrix design intended to reconcile efficiency requirements concerning globally integrated legal practices as well as local responsiveness to clients' needs.

Beta - the second firm in our sample - had taken a path of moderate yet stable growth pre-1998, at a time when other competitors in Germany's legal market had grown at a breathtaking pace. Starting from a focus on a narrow range of legal practice areas, the firm had also gained a reputation over time in a number of additional areas and had thus achieved a solid position among the top 20 commercial law firms at the beginning of the investigation period. Between 1998 and 2002, when the merger wave took off in Germany's legal market, the cross-border merger option as a basis for a new international strategy was discussed within Beta. In contrast to many of its competitors, however, the partners finally declined to pursue this option. As a result, the firm did not abandon its traditional service approach along the lines of relationship lawyering and continued to handle cross-border cases through its existing network of cooperation agreements with law firms in other countries.

The third firm - Gamma - had been formed through a series of cross-regional mergers in the 1980s and 1990s, and had thus far been highly successful in achieving a leading position among the top-tier commercial law firms by combining internal and external growth measures. One important outcome of the firm's policy of swift expansion and the integration of high number of competitors was a highly differentiated organisational structure. On the administrative side, Gamma had achieved high procedural and structural coherence at the start of the investigation period, and was widely considered to be a model 
of a well-managed law firm. However, on the advisory side, regional and legal practice groups within Gamma only maintained loose connections with one another owing to their heterogeneous historic origins. In the transformation period from 1998 to 2002 that rocked organically grown structures in Germany's legal market, the firm's partners discussed the option of merging with a foreign partnership in order to realign its hitherto diffuse international strategy. Industry experts regarded the firm as an attractive partner for a cross-border merger, because Gamma had a strong reputation in a number of legal practice areas as well as a solid client base. However, internal discussion among the partners did not provide a clear vote in favour of a merger. This led supporters of the merger option to spin off and join a law firm in another county, which ultimately resulted in the complete breakup of Gamma.

The fourth firm in our study - Delta - was a highly integrated organisation that had been formed as a result of a cross-border merger two months before the start of our fieldwork. According to the merger schedule, which was supervised by a global integration committee, the postmerger integration process was scheduled for completion within five months. In contrast to the organisational structure of most of its competitors, Delta's structure was designed along key legal practices, whereas the prevailing regional structures of the merging organisations were completely abandoned by the new organisation. Other features of the new organisation were standardised accounting procedures and partner status with organisation-wide scope. The high degrees of formalisation and standardisation had been chosen purposefully in the course of the merger after alliances with other competitors had failed owing to non-transparent structures and procedural uncertainty.

Like many firms among the top 20 in Germany's legal market, Epsilon - the fifth firm we investigated - had experienced strong growth until 1998. However, in contrast to the majority of its competitors, the option of expanding through mergers had not been considered by management, which had instead focused on organic growth. To develop the firm's international operations, the buildup of a network of foreign offices had been initiated at an early stage of the industry's development. Epsilon's strategic alignment as well as the corresponding developmental measures in this phase included an advisory approach that was highly focused on client needs and offered a complete range of professional services in business law. To support internal growth and to implement a compensation system that was partly based on performance, the firm had also started developing advanced administrative structures from an early stage. As a result, some characteristics of the managed firm and the transaction lawyering approach could already be observed at Epsilon in 1998.

Concerning the research questions addressed in our study, we considered a qualitative research methodology (Kleining 1982; Mayring 1990; Lamnek 1995) to be the most appropriate empirical approach. In view of the lack of empirical studies dealing with the outlined research questions, our empirical study relied on a grounded theory approach (Glaser/Strauss 1967) in order to develop a framework for providing a description and simple explanation of the investigated phenomena. Our empirical study involved a comparative analysis of five case studies from the top 20 firms in Germany's legal market between 1998 and 2002. The empirical sample was based on qualitative data both from 12 semi-structured interviews with an average duration of 75 minutes and from the analysis of 29 primary documents (Witzel 1982, 1985; Yin 1984; Pettigrew 1990; Miles/Huberman 1994), mostly articles or speeches authored by the interviewees. The sample sought to ex- 
plore the change of cognitive structures in the context of law firms' strategic renewal processes. Owing to the exploratory nature of our empirical analysis, we emphasised the conceptualisation of the relevant data and terminology as well as the development of core categories and concepts. To complement the findings from our interviews and documentary analyses, further data was collected through participant observation and the coding of secondary documents. Figure 6 provides a methodological overview of our research project.

\begin{tabular}{|c|c|c|}
\hline $\begin{array}{l}\text { Specifying Research } \\
\text { Questions \& Developing } \\
\text { Conceptual Framework }\end{array}$ & $\begin{array}{l}\text { Data Collection } \\
\text { (Case Studies) }\end{array}$ & $\begin{array}{l}\text { Data Analysis \& } \\
\text { Comparison }\end{array}$ \\
\hline $\begin{array}{l}\text { Research methods } \\
\text { - Interviews \& discussions with } \\
\text { industry experts } \\
\text { - Development of conceptual } \\
\text { framework } \\
\text { - Selection of cases }\end{array}$ & $\begin{array}{l}12 \text { focussed interviews } \\
\text { ("Problemzentrierte Interviews"; } \\
\text { Witzel 1985) } \\
\text { - Documentary analysis } \\
\text { ( } 29 \text { published interviews, } \\
\text { articles, speech manuscripts } \\
\text { etc.) }\end{array}$ & $\begin{array}{l}\text { - Within-case analysis } \\
\text { - Cross-case analysis } \\
\text { - Analysis of relevant literature } \\
\text { - Development of hypotheses }\end{array}$ \\
\hline $\begin{array}{l}\text { Methodological intent } \\
\text { - Specification of unit of analysis } \\
\text { (internal validity) } \\
\text { - A priori specification of } \\
\text { constructs (construct validity) } \\
\text { - Theoretical sampling of cases } \\
\text { (external validity) }\end{array}$ & $\begin{array}{l}\text { Theoretical sampling of inter- } \\
\text { views (flexible methods of data } \\
\text { collection) } \\
\text { - Triangulation (multiple sources } \\
\text { of evidence) } \\
\text { - Documentation of data } \\
\text { collection (reliability) } \\
\text { - Validation of constructs \& } \\
\text { relationships } \\
\text { - Theoretical saturation }\end{array}$ & $\begin{array}{l}\text { - Comparative analysis } \\
\text { (Reaching internal \& external } \\
\text { validity by asking questions \& } \\
\text { making comparisons) } \\
\text { - Linking of categories \& sub- } \\
\text { categories } \\
\text { - Integration of data } \\
\text { - Generalisation \& theory } \\
\text { development }\end{array}$ \\
\hline
\end{tabular}

Figure 6: Overview of methodology

\section{Two patterns of cognitive development}

The results of our case studies provide new insights into the cognitive aspects of strategic renewal under turbulent environmental conditions. Regarding the question how cognitive structures change in the course of strategic change processes in highly dynamic and complex environments, two generic developmental patterns could be observed in the ways organisational members deal with unfamiliar environmental events (Barr 1998). One important assumption underlying the case studies was that, under turbulent environmental conditions, unfamiliar events are more likely to occur than under stable and less complex conditions (Eisenhardt/Martin 2000).

According to the first pattern, the development of corresponding interpretations of environmental events can be described as a process of accumulating information in which the initially diffuse interpretations of perceived environmental cues become more elaborate and concrete over time (diffuse-concrete pattern). Among the five cases in our study, such a process of accumulating information could be observed in the case of Gamma, where 
concrete approaches for an international strategy were ultimately developed too late to ensure the organisation's survival.

According the second pattern, a set of concrete and well-defined concepts or assumptions about the organisational environment is continuously available within the organisation, regardless of the degree of familiarity with perceived environmental events. In light of new environmental perceptions, these concepts are either selectively modified over time with regard to some specific aspects or logical interrelationships or are completely replaced with new but equally concrete interpretations (e.g. via imitation of competitor choices; Greve 1998). Thus, in both scenarios, the cognitive change process implies that concrete interpretations are followed by equally concrete though more or less changed interpretations (concrete-concrete pattern). Among the four successful cases, both facets of the concrete-concrete-pattern could be observed. The case of Beta provides an example of a developmental process in which the organisational members' interpretations remained stable over time. In spite of various environmental events that occasionally incited discussions about the firm's strategy, the initially chosen strategic approach remained largely intact and merely underwent minor changes. In contrast, in the cases of Alpha, Delta, and Epsilon, a rapid shift of interpretations, resulting in a complete replacement of existing cognitive structures by new interpretations, could be observed. However, all four cases were characterised by a development from a set of concrete interpretations to a new but equally concrete set of interpretations.

While the first developmental pattern - proceeding from initially diffuse and ill-defined interpretations of environmental events to more concrete interpretations in which environmentally related information is accumulated over time - largely corresponds to the findings of Isabella (1990) and Barr (1998) on the change of cognitive structures in the context of processes of organisational change, the second developmental pattern stands in sharp contrast to the findings of these two studies. According to Barr, interpretations of novel or unfamiliar environmental events develop in four stages from diffuse, to more concrete and well-defined concepts, as suggested by Isabella (diffuse-concrete pattern in the case of novel or unfamiliar events). However, in the case of familiar or expected events, organisational members draw on already existing interpretations that are slightly re-interpreted or modified without losing their prior level of concreteness or specificity (concreteconcrete pattern in the case of familiar or expected events). In contrast, our study results support the position shared by various authors (Smircich/Stubbart 1985; Gustafson/Reger 1995; Lissack/Roos 2001; Lissack/Letiche 2002; Oliver/Roos 2003) that, within organisations with well-developed identities, the process of continuous organisational adaptation and information gathering under turbulent environmental conditions is replaced by mechanisms that ensure stability and consistency of organisational activities. In this context, the availability of concrete and consistent environmental interpretations assumes a key role in the continuity of organisational activities.

It should be noted that under conditions of high environmental turbulence, the occurrence of this phenomenon is independent from the level of unfamiliarity of perceived environmental events, leading to a concrete-concrete pattern in the case of unfamiliar events, which is in contrast to the findings of Barr (1998). Within the organisation, the objective of collecting accurate environmental information thus seems to be replaced by the objective of maintaining a set of mutually consistent interpretations (Daft/Lengel 1986; Starbuck/Milliken 1988; Weick 1995; Lissack/Roos 2001; Lissack/Letiche 2002; Oliver/Roos 
2003). As a result, the deciding factor for a specific developmental pattern is the stability level and consistency of the organisational activities bundle as well as the organisational identity that informs these activities. Thus, it can be assumed that the stronger and more elaborate the organisational identity, the higher the probability under dynamic and complex environmental conditions that novel or unfamiliar environmental events are processed on the basis of existing concrete interpretive schemes.

The adoption of a cognitive process pattern based on the gradual modification of already existing, concrete interpretations of the organisational environment is consistent with the assumption of bounded rationality in organisational decision-making (Simon 1976, 1979), which holds that dynamic and complex environmental conditions are dealt with by drawing on stabilising and complexity-reducing interpretations and corresponding organisational activities. Thus, the organisation provides various cognitive simplification mechanisms (Schwenk 1984) that enable decision-making at the individual level within the organisation. From a interpretive perspective, these mechanisms help preserve the core elements of the organisation's identity and thus help to constitute it (Dutton/Dukerich 1991). However, the extent to which environmentally related interpretations must be modified may vary depending on the degree of perceived environmental volatility (Gustafson/Reger 1995; Lissack/Roos 2001; Oliver/Roos 2003). Our study results also supplement or further develop those approaches that emphasise the organisation's capability to flexibly adapt to the prevailing degree of environmental turbulence (e.g. Eisenhardt/Bourgeois 1988; Barr et al. 1992; Brown/Eisenhardt 1997; Eisenhardt/Brown 1998, 1999; Eisenhardt/Martin 2000).

It should be noted that the two identified patterns of cognitive development are ideal types and do not depict the developmental process of any specific organisation, but rather represent two generic ways in which environmental events can impact the corresponding interpretations within organisations. Developmental processes that can unequivocally be attributed to the diffuse-concrete or concrete-concrete patterns are rarely observed in practice. Rather, there will be specific developmental patterns that tend to match one of these two ideal types. In the context of the five cases in our empirical study, Gamma's development largely corresponds with the diffuse-concrete pattern, whereas the cases of Alpha, Beta, Delta and Epsilon widely match with the concrete-concrete pattern. In the latter cases, there were clear-cut, concrete ideas in place about the upcoming strategic challenges at the start of the market entry of UK and U.S. law firms and the consolidation wave in Germany's legal market as well as about the adequate responses to these two important trends within the competitive environment.

The two cognitive process patterns described in this study are similar to the activity-oriented process patterns identified by Siggelkow (2002), who studied the development of specific configurations of organisational activities (Porter 1985, 1996) at a U.S.-based asset management company. The two alternative developmental paths distinguished by Siggelkow (2002) are the gradually increasing size and complexity of simple configurations by adding new activities related to strategic key elements (patch-by-patch; see also Eisenhardt/Brown 1999) - and the increasing refinement and elaboration of an already more or less complete, specific set of mutually consistent organisational activities (thin-tothick). In the case of a patch-by-patch pattern, which entails a stepwise extension of the range of activities, one strategic core element (e.g. focusing on top-quality advisory services) that is embedded in supporting activities and resources within the organisation is 
being elaborated and placed at the centre of all organisational activities (Porter 1996) before it is supplemented by other strategic elements at a later stage of development.

In the case of a thin-to-thick process pattern, which is characterised by the gradual elaboration and refinement of already existing interpretations, most of the strategic key elements are already in place at the start of the developmental process, although their relationships with supporting activities and resources may to some extent still be in flux. In the course of the organisational development process, these relationships will become more stable and will be gradually supplemented by additional activities and resources. At the cognitive level, the change process of environmentally related interpretive schemes in our study can be described in a similar way: In the context of developmental processes following the diffuse-concrete pattern (e.g. in the case of Gamma), initially incomplete and diffuse interpretations are gradually supplemented by collecting environmentally related information and thus become more concrete over time. In contrast, the concrete-concrete process pattern, which was most clearly observable in the case of Beta, corresponds with an already existing, internally consistent configuration of key interpretations that are supplemented by additional matching interpretations.

Besides its focus on the cognitive rather than the behavioural level, a pivotal difference between the results of our empirical study and the two process patterns outlined by Siggelkow is that already existing, concrete configurations of interpretations can be swiftly replaced by new, alternative configurations through a rapid reversal of interpretations for instance, a shift from relationship lawyering to transaction lawyering (e.g. in the cases of Alpha and Delta). Another difference concerns the question how the relationship between the current environmental turbulence level and the likelihood of a specific process pattern must be characterised. In accordance with Brown/Eisenhardt (1999), Siggelkow (2002) assumes that the further elaboration of an existing set of activities (thin-to-thick) occurs in a stable environment, whereas a stepwise extension pattern (patch-by-patch) will be observed under turbulent environmental conditions. However, the results of our study concerning the cognitive development patterns lead to the opposite conclusion. Thus, we suggest that the diffuse-concrete pattern, which corresponds with a process of stepwise extension of the range of strategic elements, is associated with stable environmental conditions, while the concrete-concrete pattern is associated with a turbulent organisational environment.

\section{The impact of changing cognitive structures on organisational success}

Based on the results of our empirical study, the second underlying research question sought to clarify how the change of cognitive structures under dynamic and complex environmental conditions affects organisational performance. This also involves the question how changing cognitive structures might impede organisational success in the context of failed change initiatives. If organisational survival is used as a measure for organisational success, four of the five law firms we investigated (i.e. Alpha, Beta, Delta and Epsilon) can be regarded as successful, since they managed to stay in the top segment of Germany's legal market between 1998 and 2002. In three of the four successful firms, strategic migration occurred (i.e. successful change initiatives aimed at shifting the firm's position from one strategic group to another). However, one of the four successful law firms (Beta) chose to retain its position within the initial strategic group. In contrast, Gamma's developmental process must be regarded as unsuccessful, since the firm finally fell apart and disap- 
peared as a competitor from the top-level segment. Gamma's breakup is ultimately the outcome of a failed change initiative (originally aimed at merging with a major law firm from another country) that had been launched by the management but had been delayed and that failed to get the approval of the majority of the partners.

In marked contrast to its four competitors, Gamma could not be unequivocally and consistently associated with relationship lawyering or transaction lawyering on the basis of the identified cognitive structures and the corresponding organisational activities; instead, it combined elements of both strategic approaches. Some of the most important aspects associated with the relationship lawyering approach were the undisputed pre-eminence of the consensus principle, the comparatively low leverage between the firm's partners and its professional employees, the high relevance of maintaining strong client relationships, and the traditional lock-step system for determining partner income within the firm. However, some aspects that might justify relating Gamma to transaction lawyering were its existing well-developed administrative structures and its attentiveness to the guiding principle of the managed firm, the aspiration to offer a full range of legal advisory services to business clients, the efforts to internationalise, and the high awareness of branding.

Besides its ambiguous strategic approach and its inconsistent bundle of corresponding activities, Gamma was also characterised by a highly decentralised organisational structure that did not include any platforms for consensus-building within the partnership (e.g. frequent and regular meetings of special task teams or executive boards, internal seminars, local offices with key influence on organisational consensus-building and decision-making, etc.). The case study results indicate that the lack of platforms for consensus-building activities contributed to the development of concrete yet highly heterogeneous interpretations of environmental events within the partnership in the second phase of the investigated developmental process. These findings suggest that organisational underperformance or even failure is facilitated by a lack of concrete, collectively developed cognitive structures (Evans and Davis 2005). In this view, a prerequisite for the success of organisational change processes is that the dissolution of existing interpretive structures as well as the development of new interpretive structures is complemented within the partnership by an intensive sense-making process by members. From an interpretive perspective (Smircich 1983; Gioia/Sims 1986; Weick/Bougon 1986; Weick 1995), the lack of platforms for the interpersonal exchange of attitudes, experiences and interpretations explains why, in the case of Gamma (unlike the rest of the sample), no reference to partnership identity could be found in documents. This suggests that the aspect of organisational identity was not perceived by the firm's management in a way that served as a point of reference to justify strategic objectives.

In contrast, the four successful firms in our sample were characterised by a clear-cut strategic approach at the cognitive level as well as by a consistent bundle of activities at the behavioural level. In the first phase (i.e. until 2000), Alpha, Beta and Delta were clearly focused on the relationship lawyering approach. The fact that Epsilon had already adopted some elements of transaction lawyering at this stage is attributed to the early start of the change process initiated by the firm's management. This does not indicate any lack of analytical clarity on the part of the firm's strategic approach although since - of all the five cases - it was Epsilon where the most vivid and well-structured discussions about strategic issues took place. In the second phase, Alpha, Delta and Epsilon adopted the transac- 
tion lawyering approach, whereas Beta - which was characterized by a high tolerance for inconsistency - preserved its traditional approach. In these four cases, success did not depend on how the firms reacted to collectively perceived environmental changes as long as the specific reactions were internally consistent (Child 1977; Drazin/Van De Ven 1985; Westley 1990; Doty et al. 1993; Weick 1995; Moorman/Miner 1998; Evans/Davis 2005; Kaplan 2008; Huy 2009). Thus, both relationship lawyering and transaction lawyering turned out to be equally valid strategic options for attaining sustainable competitive positions. In this context, the creation and preservation of an organisational identity that corresponds to the chosen strategic approach was a key characteristic of the surviving firms.

All four successful partnerships had restricted themselves to one or two head offices (mostly the home offices of the founding partners), which served as platforms for consensus-building activities. Thus, unsurprisingly, the documents analysed in our study for all four successful cases included references to the matter of preserving the firm's identity. However, in the case of Epsilon, professionals also frequently moved from one regional office to another within the firm. In the cases of Beta and Epsilon, the concern for company identity had a substantial impact on the decision to not embark on a cross-border merger, whereas Alpha and Delta did not see any contradiction between preserving organisational identity and merging with law firms from other countries. In more general terms, these findings suggest that the stronger the organisational identity and its consistency with the chosen strategic approach, the lower the risks of organisational failure resulting from changing cognitive structures under dynamic and complex environmental conditions. However, it should be noted that Epsilon, which represented a special case, since the change process initiated by the firm's management did not result in a shift to the aspired strategic group within the sample period (between 1998 and 2002), ultimately disintegrated some years later owing to growing disputes among leading partners about the objectives and outcomes of the firm's development. Hence, it can be concluded that while the failure of the change initiative had not produced any immediate impact on the internal consistency of cognitive structures and activity bundles as well as on the partnership's survival during the study period, its ripple effects apparently deprived Epsilon over time from two vital prerequisites for its long-term survival. In contrast, the remaining three firms (Alpha, Beta and Delta) remained safely positioned among the leading German law firms and were still thriving 12 years later.

\section{Implications}

Extant theory on cognitive processes in the context of strategic change holds that effective organisational adaptation to unfamiliar environmental events relies on a process in which managers' diffuse assumptions about the environment are elaborated over time as additional information is collected (Isabella 1990; Barr 1998). In contrast, the results of our study suggest that effective organisational adaptation in the context of turbulent environmental conditions - where most environmental events will be perceived as unfamiliar does not depend on the collection of detailed and specific information, but on the capabilities of organisational members to build heuristic, well-developed ad hoc interpretations on incomplete information. In the course of strategic renewal, these interpretations will in some cases be modified as further environmental events or challenges are perceived. However, our results show that, irrespective of whether or not change is sought, in order to effectively deal with perceived strategic challenges, it is essential that internal consistency of 
cognitive structures is ensured within the organisation throughout the strategic renewal process.

Based on the comparison of two empirical paths of cognitive development (i.e. presence vs. absence of cognitive change), Barr et al. (1992) concluded from their empirical findings that organisational survival under turbulent environmental conditions requires that managers adequately assess these conditions and modify their environmentally related interpretations in light of newly perceived events. However, our study results emphasise the relevance of consensus-building and identity-forming mechanisms for organisational survival under complex and dynamic environmental conditions, and thus complement the findings of Barr et al. (1992). In light of our findings, the extent of a law firm's ability to function with temporary inconsistencies between environmental perceptions and organisational strategy appears to have a moderating impact on the likelihood of a change in existing cognitive structures in the context of new environmental events.

Our study contributes to the development of a process view of strategic change in the professional services sector, which is an especially rewarding empirical study area owing to its highly dynamic and complex nature (Løwendabl/Revang 1998). We describe the evolutionary pattern of cognitive structures in professional service firms as a sequence of heuristic but well-developed interpretations of environmental events, complementing existing models on the evolution of cognitive structures in strategic renewal processes by a 'gestalt' view of organisational change. Further, we emphasise the role of the internal coherence of cognitive structures and corresponding organisational activities in the context of organisational adaptation to turbulent environments.

One additional contribution of our study of the strategic analysis of law firms lies in the identification and description of the alternative strategy types of relationship lawyering and transaction lawyering as well as its associated cognitive structures and activities. These two concepts provide the cornerstones of an analytical framework for characterising the pressures that competitors in the top-level segment of Germany's legal market have been exposed to since the market entry of large Anglo-Saxon law firms and legal advisory groups to the 'big four' accounting firms. These two concepts also provide conceptual anchors for distinguishing between strategic groups within this market segment by drawing on the two dimensions of leverage and degree of internationalisation, as well as for describing strategic migration phenomena as they occurred in the merger wave among German law firms between 1998 and 2002.

\section{References}

Abrahamson, E./Fombrun, C. J. (1994): Macrocultures: Determinants and consequences, in: Academy of Management Review, Vol. 19, S. 728-755.

Baden-Fuller, C./Volberda, H. (1997): Strategic Renewal: How Large Complex Organisations Prepare for the Future, in: International Studies of Management \& Organisation, Vol. 27, S. $95-115$.

Barney, J. B. (1991): Firm resources and sustained competitive advantage, in: Journal of Management, Vol. 17, S. 99-120.

Barr, P. S. (1998): Adapting to unfamiliar environmental events: A look at the evolution of interpretation and its role in strategic change, in: Organization Science, Vol. 9, S. 644-669. 
Barr, P. S./Stimpert J. L./Huff, A. S. (1992): Cognitive Change, Strategic Action, and Organizational Renewal, in: Strategic Management Journal, Vol. 13, S. 15-36.

Brock, D. M. (2006): The changing professional organization: A review of competing archetypes, in: International Journal of Management Reviews, Vol. 8, S. 157-174.

Brown, S. L./Eisenhardt, K. S. (1997): The Art of Continuous Change: Linking Complexity Theory and Time-paced Evolution in Relentlessly Shifting Environments, in: Administrative Science Quarterly, Vol. 42, S. 1-34.

Burgelman, R. A. (1994): Fading memories: A process theory of strategic business exit in dynamic environments, in: Administrative Science Quarterly, Vol. 39, S. 24-56.

Burgelman, R. A. (1996): A process model of strategic business exit: Implications for an evolutionary perspective on strategy, in: Strategic Management Journal, Vol. 17, S. 193-214.

Chakravarthy, B. S./White, R. E. (2002): Strategy Process: Forming, Implementing and Changing Strategies, in: Pettigrew, A./Thomas, H./Whittington, R. (Hrsg.): Handbook of Strategy and Management, London u.a., S. 182-205.

Child, J. (1977): Organization: A guide to problems and practice, London.

Cooper, D. J./Hinings C. R./Greenwood, R./Brown, J. L. (1993): Sedimentation and Transformation in Organisational Change: The Case of Canadian Law Firms, in: Organisation Studies, Vol. 17, S. 623-647.

Covaleski, M. A./Dirsmith, M. W./Heian J. B./Samuel, S. (1998): The Calculated and the Avowed: Techniques of Discipline and Struggles over Identity in Big Six Public Accounting Firms, in: Administrative Science Quarterly, Vol. 43, S. 293-327.

Daft, R. L./Lengel; R. H. (1986): Organizational information requirements, media richness, and structural design, in: Management Science, Vol. 32, S. 554-571.

Doty, D. H./Glick W. H./Huber G. P. (1993): Fit, equifinality, and organizational effectiveness: A test of two configurational theories, in: Academy of Management Journal, Vol. 36, S. 1196-1250.

Drazin, R./Van de Ven, A. H. (1985). Alternative forms of fit in contingency theory, in: Administrative Science Quarterly, Vol. 30, S. 514-539.

Dutton, J. E./Dukerich J. M. (1991): Keeping an eye on the mirror: Image and identity in organizational adaptation, in: Academy of Management Journal, Vol. 34, S. 517-554.

Dunn, P./Baker R. J. (2003): The Firm of the Future: A Guide for Accountants, Lawyers, and Other Professional Services, New Jersey.

Eisenhardt, K. M./Bourgeois L. J. (1988): Politics of strategic decision making in high-velocity environments: Towards a midrange theory, in: Academy of Management Journal, Vol. 31, S. 737-770.

Eisenhardt, K. M./Brown S. L. (1998): Competing on the Edge: Strategy as structured chaos, in: Long Range Planning, Vol. 31, S. 786-789.

Eisenhardt, K. M./Brown S. L. (1999): Patching: Restitching business portfolios in dynamic markets, in: Harvard Business Review, Vol. 77, S. 72-82.

Eisenhardt, K. M./Martin J. A. (2000): Dynamic capabilities: What are they?, in: Strategic Management Journal, Vol. 21, S. 1105-1121.

Empson, L. (2000): Merging professional service firms, in: Business Strategy Review, 11, 39-46.

Empson, L. (2001): Knowledge management in professional service firms, in: Human Relations, Vol. 54, S. 811-817. 
Evans, W. R./Davis W. D. (2005): High-Performance Work Systems and Organizational Performance: The Mediating Role of Internal Social Structure, in: Journal of Management, Vol. 31, S. 758-775.

Floyd, S. W./Lane P. J. (2000): Strategizing throughout the organisation: Managing the role conflict in strategic renewal, in: Academy of Management Review, Vol. 25, S. 154-177.

Gioia, D. A./Sims H. P. (1986): Introduction: Social cognition in organizations. in: Sims, H. P./ Gioia, D. A. (Hrsg.): The thinking organization: Dynamics of organizational social cognition, San Francisco.

Glaser, B./Strauss, A. (1967): The discovery of grounded research: Strategies for qualitative research, New York.

Gmür, M./Kaiser, S./Kampe, T. (2009): Leistungsorientiertes Personalmanagement in Wirtschaftskanzleien. Auswirkungen auf HRM-Effektivität und Commitment, in: Die Unternehmung, Vol. 63, S. 395-421.

Greenwood, R./Empson, L. (2003): The Professional Partnership: Relic or Exemplary Form of Governance?, in: Organization Studies, Vol. 24, S. 909-933.

Greenwood, R./Hinings, C. R./Brown, J. L. (1990): „P2-Form“ strategic management: Corporate practices in professional partnerships, in: Academy of Management Journal, Vol. 33, S. 725-755.

Greenwood, R./Hinings C. R./Brown, J. L. (1994): Merging Professional Service Firms, in: Organization Science, Vol. 5, S. 239-257.

Greenwood, R./Li, S. X./Prakash, R./ Deephouse, D. L. (2005); Reputation, Diversification, and Organizational Explanations of Performance in Professional Service Firms, in: Organization Science, Vol. 16, S. 661-673.

Greve, H. R. (1998): Managerial cognition and the mimetic adoption of market positions: What you see is what you do, in: Strategic Management Journal, Vol. 19, S. 967-988.

Grewe, T. (2008): Professional Service Firms in einer globalisierten Welt: Eine strategische Analyse am Beispiel von Wirtschaftsprüfungsgesellschaften und Unternehmensberatungen, Wiesbaden.

Gustafson, L. T./Reger, R. K. (1995): Using organizational identity to achieve stability and change in high velocity environments, in: Academy of Management Best Paper Proceedings, S. 464-468.

Huff, A. S. (1982): Industry influences on strategy reformulation, in: Strategic Management Journal, Vol. 3, S. 119-131.

Huy, Q. (2009): Interaction between Cognition and Emotion on Processes of Strategic Renewal, in: Academy of Management Best Paper Proceedings, S. 1-6.

Isabella, L. A. (1990): Evolving interpretations as a change unfolds: How managers construe key organisational events, in: Academy of Management Journal, Vol. 33, S. 7-41.

Kaiser, S./Ringlstetter, M. (2010): Strategic Management of Professional Service Firms, Berlin.

Kaplan, S. (2008): Cognition, Capabilities, and Incentives: Assessing Firm Response to the Fiber-Optic Revolution, in: Academy of Management Journal, Vol. 51, S. 672-695.

Kleining, G. (1982): Umriß zu einer Methodologie qualitativer Sozialforschung, in: Kölner Zeitschrift für Soziologie und Sozialpsychologie, Vol. 34, S. 224-253.

Lamnek, S. (1995). Qualitative Sozialforschung, Beltz / PVU, Weinheim.

Lee, K./Pennings, J. M. (2002): Mimicry and the market: Adoption of a new organizational form, in: Academy of Management Journal, Vol. 45, S. 144-162.

Lissack, M./Roos, J. (2001): Be coherent, not visionary, in: Long Range Planning, Vol. 34, S. 53-70. 
Lissack M./Letiche, H. (2002): Complexity, Emergence, Resilience, and Coherence: Gaining Perspective on Organizations and their Study, in: Emergence, Vol. 4, S. 72-94.

Lounsbury, M. (2002): Institutional Transformation and Status Mobility: The Professionalization of the Field of Finance, in: Academy of Management Journal, Vol. 45, S. 255-266.

Løwendahl, B./Revang, Ø. (1998): Challenges to existing strategy theory in a postindustrial society, in: Strategic Management Journal, Vol. 19, S. 755-773.

Løwendahl, B. (2005): Strategic Management of Professional Service Firms, Copenhagen.

Maister, D. H. (2003): Managing the Professional Service Firm, New York.

Mayring, P. (1990): Einführung in die qualitative Sozialforschung, München.

McKenna, P. J./Maister D. H. (2002). First among equals: How to manage a group of professionals, New York.

Melin, L. (1992): Internationalization as a strategy process, in: Strategic Management Journal, Vol. 13, S. 99-118.

Miles, M. B./Huberman, A. M. (1994): Qualitative data analysis, Thousand Oaks.

Moorman, C./Miner, A. (1998): Organizational Improvisation and Organizational Memory, in: Academy of Management Review, Vol. 22, S. 48-79.

Müller-Stewens, G./Drolshammer, J./Kriegmeier, J. (1999): Professional Service Firms - Branchenmerkmale und Gestaltungsfelder des Managements, in: Müller-Stewens, G., Drolshammer, J./ Kriegmeier, J. (Hrsg.). Professional service firms: Wie sich multinationale Dienstleister positionieren, Frankfurt a. M.

Nelson, R./Winter, S. (1982). An evolutionary theory of economic change, Cambridge (Mass.).

Oliver, D./Roos, J. (2003): Dealing with the unexpected: Critical incidents in the LEGO Mindstorms team, in: Human Relations, Vol. 56, S. 1057-1082.

Osborne, J. D./Stubbart, C. I./Ramaprasad A. (2001): Strategic groups and competitive enactment: A study of dynamic relationships between mental models and performance, in: Strategic Management Journal, Vol. 22, S. 435-454.

Pettigrew, A. M. (1990): Longitudinal field research on change: Theory and practice, in: Organization Science, Vol. 1, S. 267-292.

Porac, J. F./Thomas, H./Baden-Fuller, C. (1989): Competitive groups as cognitive communities: The case of the Scottish knitwear manufacturers, in: Journal of Management Studies, S. 397-416.

Porter, M. (1980): Competitive Strategy, New York.

Porter, M. (1985): Competitive Advantage, New York.

Porter, M. (1996): What is Strategy?, in: Harvard Business Review, Vol. 74, S. 61-78.

Reger, R. K./Huff, A. S. (1993): Strategic groups: A cognitive perspective, in: Strategic Management Journal, Vol. 14, S. 103-124.

Schwenk, C. R. (1984): Cognitive simplification processes in strategic decision-making, in: Strategic Management Journal, Vol. 5, S. 111-128.

Scott, M. C. (1998): The Intellect Industry, Chichester.

Sherer, P. D./Lee, K. (2002): Institutional change in large law firms: A resource dependency and institutional perspective, in: Academy of Management Journal, Vol. 45, S. 102-119.

Siggelkow, N. (2002): Evolution toward Fit, in: Administrative Science Quarterly, Vol. 47, S. $125-159$.

Simon, H. A. (1976): Administrative Behavior: A Study of Decision-Making Processes in in Administrative Organizations, New York. 
Simon, H. A. (1979): Rational decision making in business organizations, in: American Economic Review, Vol. 69, S. 493-513.

Smircich, L./Stubbart, C. (1985): Strategic management in an enacted world, in: Academy of Management Review, Vol. 10, S. 724-736.

Smircich, L. (1983): Organizations as shared meanings, in: Pondy, L. R./Frost P. G./Morgan, G./ Dandridge, T. C. (Hrsg.): Organizational symbolism, Greenwich (Conn.).

Spender, J.-C. (1989): Industry recipes, Oxford.

Starbuck, W. H./Milliken, F. J. (1988): Executives‘ perceptual filters: What they notice and what they make sense, in: Hambrick, D. C. (Hrsg.): The executive effect: Concepts and methods for studying top managers, Greenwich (Conn.).

Volberda, H. W./van den Bosch, F. A. J./Flier B./Gedajlovic E. R. (2001): Following the herd or not? Patterns of renewal in the Netherlands and the UK, in: Long Range Planning, Vol. 34, S. 209-229.

Weick, K. E./Bougon, M. G. (1986): Organizations as cognitive maps, in: Sims, H. P./Gioia, D. A. (Hrsg.): The thinking organization: Dynamics of organizational social cognition, San Francisco.

Weick, K. E. (1995): Sensemaking in Organizations, Thousand Oaks.

Westley, F. R. (1990): Middle managers and strategy: Microdynamics of inclusion, in: Strategic Management Journal, Vol. 11, S. 337-351.

Witzel, A. (1982): Verfahren der qualitativen Sozialforschung, Frankfurt a. M.

Witzel, A. (1985): Das problemzentrierte Interview, in: Jüttemann, G. (Hrsg.): Qualitative Forschung in der Psychologie, Weinheim.

Yin, R. K. (1984): Case Study Research, Beverly Hills.

Kai-Christian Muchow, Dr., ist Inhaber der Unternehmensberatung SirrahPartners

Anschrift: SirrahPartners, Schellingstr. 44, D-80799 München, Tel: +49 (0)89/26212401, E-Mail: kmuchow@sirrahpartners.com

Günter Müller-Stewens, Prof. Dr., ist Direktor des Instituts für Betriebswirtschaft an der Universität St. Gallen

Anschrift: Universität St. Gallen, Institut für Betriebswirtschaft, Dufourstrasse 40A, CH-9000 St. Gallen, Tel: +41 (0)71/224 2357, E-Mail: guenter.mueller-stewens@unisg.ch 